\title{
Mengembangkan instrumen pengukuran kekerasan komunikasi pada kelompok WhatsApp di lingkungan kerja dosen
}

\author{
Ira Mirawati ${ }^{1}$, Asep Suryana ${ }^{2}$, Mien Hidayat ${ }^{3}$, Herlina Agustin $^{4}$ \\ 1,2,3,4 Universitas Padjadjaran, Bandung, Indonesia
}

\begin{abstract}
ABSTRAK
Berkembang pesatnya media sosial telah memberikan ruang bagi para penggunanya untuk melakukan sekaligus mendapatkan kekerasan komunikasi. Kekerasan komunikasi melalui media sosial dapat terjadi pada berbagai kalangan, termasuk di lingkungan kerja dosen. Perilaku ini terjadi baik disengaja ataupun tidak, serta hadir dalam beragam bentuk bukan semata-mata pesan yang berisi caci maki, kebencian, atau perendahan. Pengalaman kekerasan komunikasi di tempat kerja, baik sebagai pengirim maupun penerima, dapat memiliki konsekuensi bagi emosi dan perilaku kerja seseorang. Berkaitan dengan itu, penelitian ini bertujuan untuk mengembangkan sebuah instrumen pengukuran kekerasan komunikasi yang dialami dosen termasuk emosi yang dirasakan dan perilaku kerja yang dapat dipengaruhinya. Pengembangan instrumen dilakukan dengan mengelaborasi komponen-komponen kekerasan komunikasi, emosi, dan perilaku kerja dengan Affective Events Theory. Pengujian instrumen dilakukan terhadap sampel penelitian yang diambil dengan menggunakan teknik stratified random sampling terhadap dosen perguruan tinggi di kota Bandung. Hasil penelitian menunjukkan terdapat 3 dimensi yang terdiri dari 22 pertanyaan pada variabel kekerasan komunikasi, 2 dimensi yang terdiri dari 14 pertanyaan pada variabel emosi, dan 8 dimensi yang terdiri dari 25 pertanyaan pada variabel perilaku kerja dosen yang valid untuk diukur. Simpulannya adalah bahwa instrument yang dikembangkan pada penelitian ini dapat digunakan dalam penelitian yang mengukur pengaruh kekerasan komunikasi di lingkungan kerja dosen. Penelitian dengan instrumen ini disarankan menggunakan structural equation modelling dengan confirmatory factor analysis.
\end{abstract}

Kata-kata Kunci: Kekerasan komunikasi; dosen; whatsapp group; affective event theory; perilaku kerja

\section{Developing instruments to measure communication violence in the WhatsApp groups of lecturers}

\section{ABSTRACT}

The rapid development of social media has provided space for its users to have communication as well as receiving violence. The violence of communication through social media can occur in various circles, including in the work environment of lecturers. This behavior occurs intentionally or unintentionally and comes in a variety of forms, not merely messages containing verbal abuse, hatred, or humiliation. The experience of communication violence at work, both as a sender and recipient, can have consequences for one's emotions and work behavior. In this regard, this study aims to develop an instrument for measuring communication violence experienced by lecturers, including perceived emotions and work behaviors. The development of the instrument is carried out by elaborating on the components of communication violence, emotions, and work behavior with the Affective Events Theory. Instrument testing was conducted on research samples taken using stratified random sampling techniques to college lecturers in the city of Bandung. The results show that three dimensions were consisting of 22 questions on the variable of communication violence, two dimensions consisting of 14 questions on the emotional variable, and eight dimensions consisting of 25 questions on the variables of lecturer work behavior that were valid for measurement. The conclusion is that the instrument developed in this study can be used in research to measures the influence of communication violence in the work environment of lecturers, and It is recommended to use structural equation modeling with confirmatory factor analysis.

Keywords: Communication violence; lecturer; whatsapp group; affective event theory; work behaviour

Korespondensi: Dr. Ira Mirawati, S.Sos., M.Si. Fakultas Ilmu Komunikasi Universitas Padjadjaran. Jln. Raya Bandung-Sumedang Km. 21 Jatinangor, 45363.Email: ira.mirawati@unpad.ac.id 


\section{PENDAHULUAN}

Kekerasan komunikasi dapat terjadi pada berbagai lapisan masyarakat. Orang dapat menjadi pemberi atau penerima pesan berisi kekerasan baik secara disadari ataupun tidak. Selain itu, perilaku ini bukan hanya dialami oleh anak-anak, dalam tingkatan yang beragam juga menimpa orang dewasa (Randall, 2001, 2005). Risiko kekerasan komunikasi ini semakin tinggi pada pengguna media digital ketika Internet mampu menghadirkan media sosial dan aplikasi percakapan online.

Kekerasan komunikasi adalah komunikasi yang menggunakan bahasa manipulatif dan tidak selalu koersif namun dapat menyebabkan rasa takut, rasa bersalah, malu, tersindir, terbebani tugas dan kewajiban, atau terhukum (Rosenberg, 2005). Kekerasan komunikasi di tempat kerja adalah perilaku yang menyinggung, menghina, menyabotase, mengintimidasi, dan berbagai bentuk pemberian pesan negatif lainnya kepada seseorang di lingkungan kerja (Privitera \& Campbel, 2009). Kekerasan jenis baru ini dapat dilakukan oleh kelompok maupun individu terhadap seseorang yang tidak dapat mempertahankan dirinya secara mudah (Bauman, Toomey, \& Walker, 2013). Perilaku ini dapat terjadi baik disengaja ataupun tidak, serta berlangsung dalam beragam bentuk. Berkata kepada seseorang tentang bagaimana seseorang "seharusnya" atau "seharusnya tidak" pun bahkan bisa termasuk ke dalam bentuk kekerasan karena menyalahkan seseorang atas apa yang mereka lakukan. Kekerasan komunikasi bukan semata-mata pernyataan pesan yang berisi caci maki, kebencian, atau perendahan (Rosenberg, 2005).

Seperti halnya kekerasan komunikasi yang terjadi pada anak dan remaja di lingkungan pendidikan, pengalaman kekerasan komunikasi di tempat kerja dapat memiliki konsekuensi negatif bagi kesehatan fisik dan kesejahteraan emosional seseorang. Dampak kekerasan komunikasi di tempat kerja juga dapat berimbas pada hubungan korban di tempat kerja, sosial, dan keluarga (Farley, 2015). Pengkajian mengenai perilaku bermedia para pegawai di sebuah lembaga penting untuk dilakukan (Creed \& Zutshi, 2012). Ini karena kehadiran media sosial di organisasi atau lingkungan kerja, selain memberikan banyak dampak positif, juga dapat membawa dampai negatif.
Creed \& Zutshi menyatakan bahwa humor dan candaan pun bisa saja mengandung kekerasan. Menurutnya, selain dampak positifnya yang tak dapat disangkal, media berbasis Internet bisa memunculkan kecenderungan untuk menyalahgunakan hiburan atau candaan sehingga bersifat merusak dan mengganggu keterlibatan seseorang dalam organisasi.

Kekerasan melalui media percakapan digital pada orang dewasa dapat terjadi tanpa disengaja, "banyak orang melakukan kekerasan atau pelecehan di media sosial sebagai candaan tanpa menyadari bagaimana rasanya mengalami itu semua" (Mirawati, Suryana, Hidayat, \& Agustin, 2018; Mishna, Saini, \& Solomon, 2009) an online chatting group, such as WhatsApp group, is a scene of humor. As well as real-world humor, gender relations also shape humor in this virtual world. This study investigated gender differences in workplace humor among lecturers on WhatsApp group(s. Ini selaras dengan apa yang diungkap dalam penelitian D'Cruz dan Noronha pada sebuah perusahaan informasi dan teknologi di India, "kekerasan melalui media sosial di perusahaan ini bersifat tanpa batas, kongkrit, dan permanen, namun selama ini tidak disadari sebagai sebuah kekerasan" (D'Cruz \& Noronha, 2013).

Salah satu pihak yang berpotensi melakukan dan menerima kekerasan komunikasi melalui media sosial adalah dosen. Ini karena tingkat akses dosen terhadap media sosial sangat tinggi, baik dalam berkomunikasi dengan rekan kerja maupun dengan mahasiswa. Dosen adalah pendidik profesional dan ilmuwan dengan tugas utama mentransformasikan, mengembangkan, dan menyebarluaskan ilmu pengetahuan, teknologi, dan seni melalui pendidikan, penelitian, dan pengabdian kepada masyarakat (Pasal 1 Undang-Undang Republik Indonesia No 14 Tahun 2005 Tentang Guru Dan Dosen).

Penelitian yang dilakukan oleh Kristen Purcell dkk. dari Pew Research center, sebuah lembaga penelitian di bidang Internet dan teknologi, menyatakan bahwa pengajar, termasuk dosen, merupakan pihak yang sangat mungkin terkena kekerasan komunikasi melalui media digital di kalangan mereka sendiri atau dari mahasiswa karena mereka tergolong ke dalam kelompok awal dan mayoritas yang mengadopsi teknologi informasi (Purcell, Heaps, Judy, \& Linda Friendrich, 2016). Walau tidak ada angka resmi tentang kepemilikan 
media digital di kalangan dosen, namun sebuah penelitian yang dilakukan terhadap 872 responden dari 30 Perguruan Tinggi Negeri (PTN) menunjukkan bahwa penggunaan media berbasis komputer ini di kalangan dosen sangat tinggi karena mereka memerlukan teknologi ini bukan hanya sebagai alat komunikasi melainkan sarana untuk meningkatkan kapasistas pengajaran mereka (Pribadi, 2006).

Dosen-dosen yang mendapatkan yang melakukan kekerasan biasanya menganggap bahwa mereka hanya melontarkan humor dan candaan, sementara dosen yang menjadi objek humor biasanya merasa bahwa mereka dibully. Topik-topik humor yang mereka anggap sebagai bully adalah status yang belum menikah, lelucon tentang kondisi fisik "negatif", foto atau video konyol, urusan domestik rumah tangga, dan penyebutan pekerjaan yang tidak produktif. Korban juga merasa bahwa mereka adalah "minoritas" atau memiliki kekuatan yang lebih lemah (Mirawati, Suryana, Agustin, \& Hidayat, 2019).

Penelitian kekerasan komunikasi umumnya dilakukan terhadap anak dan remaja. Untuk orang dewasa masih sangat terbatas. Di negaranegara lain, penelitian mengenai kekerasan pada orang dewasa sudah banyak dilakukan mengingat kekerasan komunikasi pada orang dewasa juga dapat membawa dampak yang serius. Beberapa penelitian yang dirujuk untuk mengembangkan penelitian ini adalah "Cyberbullyingvictimization, counterproductive work behaviours and emotional intelligence at workplace" (Keskin, Ekber Akgün, Ayar, \& Kayman, 2016). Penelitian Keskin dkk. menunjukkan bahwa kekerasan komunikasi dapat menyebabkan level stress yang tinggi. Selama ini faktor yang selalu dianggap sebagai pencetus CWB adalah konflik di lingkungan kerja, namun penelitian yang dilakukan pada akhir-akhir ini menunjukkan bahwa kekerasan komunikasi melalui media siber sebagai penyebab baru yang dapat melahirkan counter productive work behavior (Keskin et al., 2016).

Selain penelitian Keskin tersebut, adapula penelitian yang berjudul "Cyberbullying at Work: In Search of Effective Guidance" (West, Foster, Levin, Edmison, \& Robirero, 2014) yang berhasil menyusun tiga kategori kekerasan komunikasi yakni: 1) Kekerasan komunikasi yang berkaitan dengan pekerjaan (work-related), diantaranya adalah perahasiaan informasi kerja dari seseorang, pengabaian opini, monitoring pekerjaan yang bersifat menekan, tekanan untuk tidak mengklaim sebuah keberhasilan, termasuk pemberian beban kerja berlebihan melalui media virtual. 2) Kekerasan komunikasi yang berkaitan dengan hubungan personal (personalrelated), mencakup gossip atau rumor tentang hubungan personal, objek canda dan lelucon, dan pengisolasian. 3) Kekerasan komunikasi yang berkaitan dengan kondisi fisik (Physical intimidating), mencakup amarah terhadap target, dan menjadikan kondisi fisik target sebagai bahan ejekan.

Heatherington \& Coyne menggunakan analisis fenomenologi interpretatif untuk memahami berbagai pengalaman cyberbullying individu-individu yang ditemui dalam lingkungan kerja. Penelitian mereka menggunakan teknik pengumpulan data berupa wawancara mendalam, yang dilakukan terhadap lima pekerja dari lapangan farmasi, pekerja amal, dan sektor-sektor universitas yang mengalami cyberbullying, Penelitian ini juga menggarisbawahi kerumitan yang muncul dari cyberbullying yaitu bahwa para pekerja harus mengorganisir hubungan kerja mereka baik secara fisik maupun secara virtual (Heatherington \& Coyne, 2014).

Sejalan dengan penelitian Heatherington dan Coyne, penelitian ini menjadi penting untuk dilakukan karena kekerasan komunikasi di lingkungan kerja menjadi suatu hal yang unik sebab korban tidak selamanya menjadi korban. Mereka tahu siapa yang menjadi pelaku dan berkesempatan untuk membalas, namun juga harus tetap memikirkan hubungan kerja yang terjalin. Heatherington dan Coyne menyatakan bahwa terdapat juga hierarki jabatan yang membuat pengalaman kekerasan komunikasi bukan hanya mempengaruhi perilaku kerja personal namun juga tim kerja.

Oleh karena itu, adalah penting untuk mengambangkan instrumen-instrumen untuk mengukur kekerasan komunikasi melalui media virtual yang dialami oleh dosen. Bukan hanya komponen kekerasan komunikasinya saja, namun juga emosi yang dirasakan serta pengaruh yang terjadi perilaku kerja. Teori yang dapat digunakan untuk mengembangkan instrumen penelitian ini adalah Affective Events Theory (AET) dari Weiss dan Cropanzano yang mereka kemukakan pada 1996. Teori ini melihat bagaimana emosi dan suasana hati 
manusia mempengaruhi perilaku kerja. AET menunjukkan bahwa karyawan bereaksi secara emosional pada hal-hal yang terjadi pada mereka di tempat kerja dan bahwa reaksi ini mempengaruhi perilaku bekerja dan kepuasan kerja, peristiwa-peristiwa tersebut memicu reaksi emosi yang positif atau negatif. Oleh karena itu, berbagai peristiwa ditempat kerja yang menyebabkan reaksi-reaksi emosional pegawai, akan mempengaruhi sikap dan perilaku ditempat kerja (Robbins \& Judge, 2008).

Roland E. Pittman menyatakan bahwa teori yang dikemukakan oleh Howard M. Heiss dan Russel Cropanzano pada tahun 1996 sebagai teori yang dikembangkan oleh psikolog organisasi namun merupakan salah satu "communication-based theory". Pittman juga menyatakan "This theory has been utilized by numerous researchers to better understand emotion from a communicative lens" (Roland E Pittman, 2016). Dengan kata lain, teori ini telah digunakan pada pada berbagai penelitian untuk memahami emosi dari lensa komunikasi. Senada dengan itu, Tourish \& Hargie (2003), menyatakan bahwa AET membantu dalam menjelaskan hubungan antara bahasa, emosi, dan pikiran seseorang, terutama dalam menjelaskan alasan-alasan dari munculnya sebuah emosi.

Mengapa kekerasan komunikasi pada media media berbasis Internet atau media digital perlu dilakukan? Media-media berbasis Internet ini biasa disebut pula media digital. Media digital adalah media yang dapat mempertukarkan konten digital melalui Internet atau jaringan komputer. Pesan dapat mencakup teks, audio, video, dan grafis. Cakupan ini menunjukkan bahwa berita dari jaringan TV, koran, atau majalah yang disajikan di situs web atau blog dapat termasuk ke dalam kategori ini. Intinya adalah sebuah media dikatakan digital didasarkan pada kemampuan menerjemahkan data analog menjadi data digital (Creeber, 2009).

Media digital mulai berkembang ketika teks dimasukkan ke Internet daripada disimpan di atas kertas seperti sebelumnya. Perkembangan itu terus berjalan pesat ketika yang dapat dipertukarkan melalui Internet bukan hanya teks, namun juga gambar, audio, dan video. Seiring dengan berjalannya waktu, Internet mulai memainkan peran yang lebih pribadi dalam kehidupan manusia. Internet tidak lagi hanya dikaitkan dengan pemerintah atau perusahaan besar namun manusia dari berbagai kalangan. Perkembangan media digital ini telah membuat orang merasa bahwa menyimpan informasi di Internet adalah sesuatu yang nyaman dan memberikan struktur yang baik. Fungsi Internet menjadi lebih berkembang. Orang-orang mulai menggunakan Internet untuk komunikasi, tujuan kreatif, penelitian, atau sekadar hiburan. Internet adalah sistem global yang luas yang menghubungkan jaringan komputer. Dengan kemampuan tersebut, Internet kemudian digunakan untuk berbagai tujuan, baik untuk bidang pemerintahan, komersial, pendidikan, sosial, dan lain-lain. Kondisi ini menunjukkan bahwa media digital benar-benar tidak bisa lepas dari kehidupan manusia modern (Creeber, 2009). Kemampuan Internet untuk menukarkan informasi dari berbagai pihak membuat manusia dapat mendengar dari berbagai sumber, bahkan termasuk informasi yang bersifat pribadi dalam posting-an yang memuat pandangan mereka sendiri.

Media digital mampu mengalihkan berbagai aktivitas manusia, baik politik, sosial, ekonomi, kultural, spiritual, bahkan seksual dari dunia nyata ke dalam bentuk subsitusi artifisial, dalam sebuah ruang bernama cyberspace. Media digital semakin menguasai komunikasi manusia ketika mampu menghadirkan media sosial. Ini ditandai dengan lahirnya blog sebagai bentuk yang menarik dari media digital. Fasilitas ini benar-benar membantu mendorong produksi dan pencarian informasi melalui Internet. Peran media baru pada komunikasi manusia semakin besar dengan berkembangnya aplikasi percakapan online yang dimulai dengan hadirnya Blackberry Messenger, WhatsApp, Line, Kakaotalk, dan lain-lain.

Di sisi lain, jumlah pengguna Internet di Indonesia dalam lima tahun terakhir selalu berada pada sepuluh besar dunia. Tahun 2015 misalnya, Indonesia menduduki peringkat ke-6 sebagai pengguna Internet terbesar di dunia. Menurut data yang dirilis oleh APJII (Asosiasi Penyelenggara Jasa Internet Indonesia), jumlah pengguna Internet pada tahun 2014 sebesar 88,1 juta. Angka tersebut naik dari 71,2 juta di tahun sebelumnya. Bahkan pada akhir 2017, e-Marketer memperkirakan, jumlah netter Indonesia bakal mencapai 112 juta orang, mengalahkan Jepang pada peringkat ke-5.

Internet dan media sosialnya semakin 
berkembang karena organisasi dan pekerja dari berbagai sektor memilihnya sebagai cara untuk menghindari cara berkomunikasi yang sulit mendapatkan feedback langsung (Lawson, 2015). Perusahaan-perusahaan mulai beralih ke media sosial dan aplikasi percakapan online demi menyederhanakan komunikasi internal. Peralihan ini didukung oleh semakin berkembangnya aplikasi percakapan online menjadi "ramah mobile". Yang dimaksud dengan "ramah mobile" menurut Lawson adalah, orang dapat mengakses aplikasi percakapan tersebut di mana saja dengan telepon pintar mereka, aplikasi-aplikasi tersebut hanya memerlukan kuota data yang rendah, namun kaya akan ekspresi yang dapat menyampaikan pesan penggunanya secara lebih komprehensif. Media sosial dan percakapan online mampu memfasilitasi percakapan yang singkat, cepat dan terbuka dalam batas yang dapat ditentukan oleh kelompok-kelompok percakapan, sehingga adalah menjadi alternatif efisien dan lebih alami seperti percakapan langsung.

Smith, Bario, dan Tokunaga mengemukakan bahwa kekerasan komunikasi di media sosial, dapat dilihat dari (Smith, Bario, \& Tokunaga, 2013): 1) Bentuk kekerasan. Ada beragam bentuk kekerasan komunikasi, diantaranya adalah kekerasan fisik, kekerasan nonfisik, kekerasan verbal, kekerasan nonverbal, kekerasan langsung, dan kekerasan tidak langsung. Kekerasan atau agresi (bahasa yang digunakan oleh Smith dkk.) di media, memang terkadang tidak terlihat seperti kekerasan. Pelaku dan penonton (atau anggota kelompok percakapan online yang bukan korban) terkadang melihatnya seperti humor atau canda belaka. 2) Repetisi, Repetisi merupakan pengulangan dari kegiatan transmisi penyampaian pesan dari pelaku terhadap penerima. Karena berulang itulah, maka terjadi akumulasi dampak pada diri penerima. Kejadian yang berulang juga mengindikasikan bahwa kekerasan tersebut bukanlah sesuatu yang insidental atau tidak sengaja belaka, namun disadari oleh pelakunya. Repetisi atau keberulangan dapat dilihat dari frekuensi seseorang menerima pesan yang berisi pelecehan atau perendahan. 3) Ketidakseimbangan kekuatan. Seperti halnya kekerasan di dunia nyata, kekerasan komunikasi di media sosial dapat terjadi dan berulang didukung oleh ketidakseimbangan kekuatan antara pelaku dan korban (Smith et al., 2013). Ketidakseimbangan itu meliputi: kesenjangan usia, kesenjangan ekonomi, kesenjangan jabatan, kesenjangan fisik, kesenjangan kepercayaan diri dan kesenjangan jumlah teman.

Sebuah penelitian yang dilakukan oleh Gurdani Yogisusanti dkk. dari Immanuel School of Health Science terhadap dosen ilmu kesehatan di Bandung menyatakan bahwa salah satu penyebab kelelahan kerja dosen adalah hubungan antarkolega yang tidak harmonis, baik hubungan langsung maupun tidak langsung (Yogisusanti, Kusnanto, Setyawati, \& Otsuka, 2014). Fakta ini menjadi dasar untuk meneliti kekerasan komunikasi melalui media sosial yang terjadi di kalangan dosen kaitannya dengan emosi dan perilaku kerja mereka.

Emosi adalah sesuatu yang dirasakan oleh seseorang di dalam dirinya. Pengalaman emosi seseorang memberi kesan terhadap sel-sel otak dan ingatan, lalu membentuk corak-corak yang mempengaruhi perilaku seseorang. Emosi merupakan kondisi perasaan seseorang yang ia ketahui penyebabnya. Contoh emosi adalah perasaan sedih karena tidak bisa mengerjakan ujian, atau perasaan takut karena melakukan kesalahan (Pirola-Merlo, Härtel, Mann, \& Hirst, 2002).

Emosi seorang pekerja dapat berubahubah. Bila emosi tidak mampu dikawal, ia akan menimbulkan masalah dalam organisasi. Oleh itu, para pegawai, termasuk dosen, perlu menangani berbagai permasalahan dan peristiwa yang mempengaruhi emosi, karena emosi yang tidak terkawal akan turut menurunkan prestasi kerja secara keseluruhan.

Basch dan Fisher mengidentifikasi dengan teori affective events bahwa emosi yang termasuk emosi positif adalah senang, suka, rela, harapan, dan antusiasme. Sementara emosi negatif meliputi sedih, benci, marah, putus asa, dan apatisme (Basch \& Fisher, 1998)

Perilaku kerja, menurut Weiss dan Beal adalah perilaku karyawan yang terlihat ketika sedang bekerja (M. Weiss \& Beal, 2005). Menurut Gomes ada delapan komponen perilaku kerja yaitu kuantitas kerja, kualitas kerja, pengetahuan tentang pekerjaan, daya kreativitas, kerja sama, kesalingbergantungan, inisiatif, dan kualitas pribadi (Gomes, 2003).

Berdasarkan latar belakang tersebut, artikel yang ditulis dari Penelitian Disertasi Doktoryang dibiayai olek Kemenristekdikti ini bertujuan 
untuk mengembangkan instrumen untuk dapat mengukur kekerasan komunikasi dialami seorang dosen dan pengaruhnya terhadap emosi serta perilaku kerja dosen. Harapannya, agar instrumen-instrumen ini dapat dijadikan sumber rujukan atau bahkan direplikasi untuk meneliti kekerasan komunikasi pada lingkungan kerja sejenis.

\section{METODE PENELITIAN}

Dari tiga jenis penelitian yang ada berdasarkan tujuannya (Adler \& Clark, 2014; Babbie, 2011;Neuman, 2014) yakni eksploratori, deskriptif, dan eksplanatori, penelitian ini merupakan penelitian eksplanatori. Penelitian eksplanatori didesain untuk menjelaskan mengapa subjek penelitian berada pada kondisi tertentu. Secara deduktif, studi eksplanatori bergerak dari sebuah pernyataan umum kepada yang lebih spesifik. Singkatnya, ia memerlukan teori untuk menentukan data apa saja yang harus dikumpulkan dalam menguji sebuah dugaan.

Untuk memperoleh data yang diperlukan dalam penelitian ini, peneliti menggunakan teknik studi literatur dan observasi kondisi awal. Kedua teknik tersebut diperlukan untuk dapat menyusun instrumen yang akan diujikan. Selanjutnya pengujian alat ukur dilakukan melalui survei dengan alat ukur kuesioner yang berisi intrumen. Kuesioner merupakan alat yang paling tepat digunakan untuk mengukur fenomena pada sebuah populasi.

Populasi penelitian atau biasa juga disebut dengan populasi target adalah elemen masyarakat dimana penelitian ini difokuskan dan target di mana hasil penelitian yang diperoleh dengan menguji sampel akan digeneralisasikan (Bless, Higson-Smith, \& Sithole, 2013). Populasi bukan sekadar manusianya saja, namun mencakup karakteristik yang menempel pada mereka. Sementara itu, sampel, adalah bagian dari jumlah dan karakteristik yang dimiliki oleh populasi tersebut (Mann \& Lackee, 2010). Semakin sampel yang dipilih tersebut memiliki karakteristik yang dekat dan mewakili populasi, maka semakin representatif sampel tersebut. untuk mengukur validitad dan reliabilitas, instrument diujikan pada tiga puluh dosen dari delapan perguruan tinggi di kota Bandung. Penelitian ini dilakukan pada Maret 2018 hingga Desember 2018.

\section{HASIL DAN PEMBAHASAN}

Dosen yang menjadi populasi penelitian ini adalah dosen perguruan tinggi, baik negeri maupun swasta di Kota Bandung. Berdasarkan data terbaru di Pusat Katalog Data dan Informasi Perguruan Tinggi Provinsi Jawa Barat, terdapat 126 perguruan tinggi aktif di Kota Bandung. Dari keseluruhan perguruan tinggi tersebut, dilakukan pemilihan berdasarkan ranking kemenristekdikti terbaru yang mencerminkan kelengkapan data pegawai, rasio jumlah dosen, performa pengelola, akreditasi institusi, serta jumlah ouput riset dan publikasi yang dielaborasi dengan ranking Webometric dan IC4U. Data ranking dari ristekdikti ini ketika dielaborasi dengan data perankingan internasional menunjukkan perguruan tinggi yang serupa, meskipun rankingnya ada perbedaan, namun kedelapan perguruan tinggi ini adalah yang tertinggi. Empat perguruan tinggi negeri ranking tersebut meliputi Institut Teknologi Bandung, Universitas Padjadjaran, Universitas Pendidikan Indonesia, dan Universitas Islam Negeri Sunan Gunung Djati Bandung. Sementara empat perguruan tinggi swasta teratas adalah Universitas Katolik Parahyangan, Universitas Pasundan, Universitas Telkom, dan Universitas Islam Bandung.

Instrumen utama penelitian ini, yakni berupa kuesioner, disebarkan setelah melalui uji coba kuesioner biasa atau questionnaire pre-testing atau pilotting. Tahapan ini harus dilakukan sebelum uji validitas dan reliabilitas agar uji validitas dan reliabilitas tidak terlalu berat dan mengulang berulang kali. Peneliti melakukan pretesting dengan merujuk pada eksperimen pengisian kuesioner yang dicontohkan oleh Raymond F. Sletto (Sletto, 1940) dan Pamela Grimm (Grimms, 2010). Dari dua jenis pretesting questionnaire yang ada, yakni participating pretest dan undeclared pretest, peneliti menggunakan participating pretest yakni meminta para responden/informan untuk menjadi sukarelawan dalam menguji coba dan memberi masukan perbaikan kuesioner.

Prosedur yang peneliti lakukan adalah: 1) Peneliti membagikan kuesioner pada dosen di dua prodi di lingkungan Universitas Padjadjaran yang terdiri dari satu prodi ilmu sosial dan satu prodi ilmu eksakta. Uji coba pada kedua prodi tersebut dilakukan secara terpisah, Jumlah dosen yang terlibat pada masing-masing uji 
coba tersebut adalah 8 orang dan mereka telah diberitahu perannya sebagai penguji kuesioner; 2) kuesioner dibagikan kepada para dosen, mereka diminta untuk mengisi sesuai keadaan yang sebenarnya dan menandai pertanyaanpertanyaan yang rancu atau tidak dapat dipahami; 3) para relawan ini lalu dikumpulkan untuk memberikan masukannya kepada peneliti dalam sebuah diskusi. Setelah memperbaiki kuesioner sesuai masukan dalam diskusi, barulah kemudian dilakukan uji validitas dan reliabilitas.

Data primer yang digunakan dalam penelitian ini perlu diuji kesahihan atau validitas dan keandalan atau reliabilitasnya karena data tersebut berasal dari jawaban responden yang mungkin dapat menimbulkan bias. Hal ini sangat penting dilakukan karena kualitas data nantinya akan sangat mempengaruhi kualitas hasil penelitian. Ini berarti pula bahwa data yang bias akan menghasilkan kesimpulan penelitian yang bias pula.

Uji validitas menunjukkan sejauh mana alat ukur yang digunakan benar-benar mengukur apa yang ingin diukur, atau secermat apa suatu alat ukur yang digunakan mengenai sasaran. Semakin tinggi validitas suatu alat tes, maka alat tersebut semakin mengenai pada sasarannya, atau semakin menunjukkan apa yang seharusnya diukur. Suatu tes dapat dikatakan mempunyai validitas tinggi apabila alat tes tersebut menjalankan fungsi ukurnya menunjukkan sejauh mana suatu alat ukur itu mengukur konstruk yang akan diukur, sehingga data yang terkumpul merupakan data yang memadai.

Untuk menguji validitas alat ukur, terlebih dahulu dicari harga korelasi antara bagianbagian dari alat ukur secara keseluruhan dengan cara mengorelasikan setiap butir alat ukur dengan skor total yang merupakan jumlah tiap skor butir.

Langkah-langkah uji validitas: a) menganggap skor butir pertanyaan sebagai nilai $\mathrm{X}$ dan skor total sebagai nilai $\mathrm{Y} ; \mathrm{b}$ ) mengkorelasikan butir-butir soal pertanyaan dengan skor total untuk masing-masing

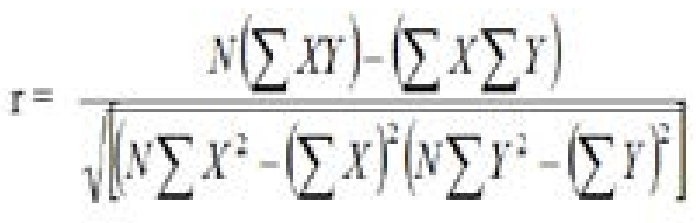

variabel. Dengan menggunakan rumus "Product Moment" (Sugiono;2005) sebagai berikut:

Keterangan:

$\mathrm{r}=$ Koefisien validitas item yang dicari

$\mathrm{X}=$ Skor yang diperoleh dari subyek dalam

tiap item

$\mathrm{Y}=$ Skor total yang diperoleh dari subyek seluruh item

$$
\begin{aligned}
& \quad \sum X=\text { Jumlah skor setiap pernyataan } \\
& \text { dikalikan skor total } \\
& \mathrm{N}=\text { Jumlah responden }
\end{aligned}
$$

Angka korelasi yang diperoleh secara statistik dibandingkan dengan angka kritik tabel korelasi nilai r. Bila $\mathrm{r}_{\text {hitung }}>\mathrm{r}_{\text {tabel }}$ maka berarti data tersebut signifikan (valid) dan layak digunakan dalam pengujian hipotesis penelitian. Dan sebaliknya bila $\mathrm{r}_{\text {hitung }}<\mathrm{r}_{\text {tabel }}$ berarti data tersebut tidak signifikan (tidak valid) dan tidak akan diikut sertakan dalam pengujian hipotesis penelitian.

Pada penelitian ini, uji validitas dilakukan dengan menggunakan program IBM SPSS Statistic versi 22. Berikut ini hasil uji validitas yang telah dilakukan:

Berikut ini adalah pernyataan-pernyataan pada instrumen yang telah teruji validitas dan tersebut: X1 yaitu bentuk kekerasan. Bentuk kekerasan terdiri dari kekerasan fisik dan kekerasan nonfisik, kekerasan verbal dan kekerasan nonverbal, serta kekerasan langsung dan kekerasan tidak langsung, dapat dilihat pada tabel 1 .

Kekerasan fisik diwakili oleh item nomor 1, responden mendapat pesan di kelompok percakapan online yang berisi kekurangan secara fisik. Kekerasan nonfisik yaitu item nomor 2: responden mendapat pesan di kelompok percakapan online yang berisi kekurangan yang tidak berkaitan dengan kondisi fisik, item nomor 3: responden mendapat pesan berisi kekurangannya berkaitan dengan pekerjaan, dan item nomor 4: seseorang pernah menegur responden di grup WhatsApp berkaitan dengan pekerjaan.

Kekerasan verbal diwakili oleh item nomor 5: Kelemahan responden disampaikan di grup WhatsApp dalam bentuk kata-kata. Sementara itu kekerasan nonverbal diwakili oleh item nomor 6 dan 7 yaitu: Foto atau video responden yang konyol disebarkan di grup WhatsApp oleh rekannya, dan rekan kerja pernah mengirim 
Tabel 1 Hasil Uji Validitas Variabel Kekerasan Komunikasi

\begin{tabular}{lllll}
\hline $\begin{array}{l}\text { Dimensi } \\
\text { Variabel }\end{array}$ & Item & $\begin{array}{l}\text { Koefisien } \\
\text { Validitas } \\
\text { (r hitung) }\end{array}$ & $\begin{array}{l}\text { Titik } \\
\text { Kritis }\end{array}$ & $\begin{array}{l}\text { V=30 } \\
\text { (r tabel) }\end{array}$ \\
\hline Bentuk & 1 & 0,714 & 0,361 & Valid \\
Kekerasan & 2 & 0,677 & 0,361 & Valid \\
& 3 & 0,853 & 0,361 & Valid \\
& 4 & 0,582 & 0,361 & Valid \\
& 5 & 0,576 & 0,361 & Valid \\
& 6 & 0,653 & 0,361 & Valid \\
& 7 & 0,525 & 0,361 & Valid \\
& 8 & 0,545 & 0,361 & Valid \\
& 9 & 0,669 & 0,361 & Valid \\
& 10 & 0,567 & 0,361 & Valid \\
& 11 & 0,525 & 0,361 & Valid \\
& 12 & 0,445 & 0,361 & Valid \\
& 13 & 0,528 & 0,361 & Valid \\
& 14 & 0,564 & 0,361 & Valid \\
Repetisi & 15 & 0,666 & 0,361 & Valid \\
& 16 & 0,715 & 0,361 & Valid \\
Kesenjangan & 17 & 0,810 & 0,361 & Valid \\
& 18 & 0,832 & 0,361 & Valid \\
& 19 & 0,809 & 0,361 & Valid \\
& 20 & 0,639 & 0,361 & Valid \\
& 21 & 0,507 & 0,361 & Valid \\
& 22 & 0,491 & 0,361 & Valid \\
\hline
\end{tabular}

Sumber: Pengolahan data penelitian, 2018

gambar atau video yang isinya bukan responden namun untuk menyindir responden.

Kekerasan langsung diwakili oleh item nomor 8: Kelemahan responden diperbincangkan di grup WhatsApp bukan dalam bentuk senda gurau melainkan serius, dan item nomor 9: Nama responden disebutkan secara jelas dalam sebuah pesan yang menurut responden merendahkannya. Sementara itu kekerasan tidak langsung diwakili oleh item nomor 10 hingga 14. Item-item tersebut adalah: Rekan kerja menuliskan kekurangan responden di grup WhatsApp yang membuat anggota grup WhatsApp menertawakannya, Responden merasa pernah mendapatkan sebuah pesan yang merendahkan ditujukan padanya meskipun pada pesan tersebut nama responden tidak disebutkan, Rekan kerja menuliskan pesan tentang responden yang isinya menyinggung perasaan responden, Jika responden menulis sebuah pesan di grup WhatsApp temantemannya tidak menanggapi, dan Teman-teman tidak antusias merespon pesan yang responden sampaikan.

Berikutnya, X1.2 yaitu Repetisi diukur oleh dua item yaitu nomor 15 dan 16 . Item tersebut adalah Jumlah pesan negatif yang diterima dari orang yang sama dan Jumlah pesan negatif yang diterima dari orang yang berbeda.

Untuk X1.3 adalah kesenjangan terdiri dari kesenjangan usia, kesenjangan ekonomi, kesenjangan jabatan, kesenjangan fisik, kesenjangan kepercayaan diri, dan kesenjangan jumlah teman. Kesenjangan usia diukur dengan item Umur responden lebih muda daripada pengirim pesan. Kesenjangan ekonomi diukur melalui item terdapat kesenjangan kondisi ekonomi antara responden dan pengirim pesan. Kesenjangan jabatan diukur dengan pertanyaan terdapat kesenjangan jabatan antara responden dan pengirim pesan. Kesenjangan fisik diukur dengan pertanyaan terdapat kesenjangan kondisi fisik responden dan pengirim pesan. Kesenjangan kepercayaan diri diukur melalui pertanyaan terdapat kesenjangan kepercayaan diri antara responden dan pengirim pesan. Dan, kesenjangan jumlah teman diukur melalui pertanyaan responden merasa jumlah temannya lebih sedikit daripada pengirim pesan.

Emosi diukur dari dua sudut, yaitu emosi positif dan emosi negatif. Emosi positif terdiri dari tujuh pertanyaan dan emosi negatif tujuh pertanyaan, dapat dilihat pada tabel 2 .

Emosi diukur dari dua sudut, yaitu emosi positif dan emosi negatif. Emosi positif terdiri dari tujuh pertanyaan yaitu: 1) responden merasa antusias ada yang mengirim pesan mengenai dirinya di grup grup WhatsApp meskipun isinya merendahkan, 2) responden menikmati obrolan di grup WhatsApp meskipun topiknya adalah kekurangan dirinya, 3) responden merasa senang saat orang-orang ramai memperbincangkan dirinya meskipun isinya adalah kekonyolannya, 4) responden tidak keberatan orang-orang membicarakan kelemahannya, 5) Dengan diperbincangkan saya merasa dilibatkan, 6) responden merasa bahwa dengan diperbincangkan di grup WhatsApp dia justru mermiliki harapan untuk menjadi lebih baik, dan 7) Responden merasakan 
Tabel 2 Hasil Uji Validitas Variabel Emosi

\begin{tabular}{lllll}
\hline Dimensi & Item & $\begin{array}{l}\text { Koefisien } \\
\text { Validitas } \\
\text { (r hitung) }\end{array}$ & $\begin{array}{l}\text { Titik } \\
\text { Kritis } \\
\mathrm{N}=30 \\
\text { (r tabel) }\end{array}$ & Validitas \\
\hline Z1 & 1 & 0,609 & 0,361 & Valid \\
& 2 & 0,681 & 0,361 & Valid \\
& 7 & 0,615 & 0,361 & Valid \\
& 8 & 0,632 & 0,361 & Valid \\
& 9 & 0,517 & 0,361 & Valid \\
& 10 & 0,572 & 0,361 & Valid \\
& 11 & 0,686 & 0,361 & Valid \\
& 3 & 0,602 & 0,361 & Valid \\
& 4 & 0,635 & 0,361 & Valid \\
& 5 & 0,618 & 0,361 & Valid \\
& 6 & 0,677 & 0,361 & Valid \\
& 12 & 0,644 & 0,361 & Valid \\
& 13 & 0,591 & 0,361 & Valid \\
& 14 & 0,776 & 0,361 & Valid \\
\hline
\end{tabular}

Sumber: Pengolahan data penelitian, 2018

kepuasan tersendiri ketika menjadi objek perbincangan di grup WhatsApp meskipun isinya menertawakannya.

Emosi negatif diukur dari pertanyaan: 1) responden merasa tertekan saat menjadi objek pembicaraan negatif teman-temannya di grup WhatsApp, 2) responden merasa marah kepada orang yang mengirim pesan merendahkan mengenai dirinya, 3) responden merasa sedih ada orang yang mengirim pesan berisi hal yang merendahkan dirinya di kelompok percakapan online, 4) responden merasa malu setiap kali ada yang menulis pesan yang merendahkannya di grup WhatsApp, 5) responden merasa frustasi setiao kali ada yang menulis pesan yang merendahkan dirinya di grup WhatsApp, 6) responden merasa kecewa pada orang-orang yang menulis pesan yang merendahkan dirinya di grup WhatsApp, dan 7) responden merasa cemas ketika kelemahannya diperbincangkan di grup WhatsApp.

Variabel perilaku kerja dosen diukur dari delapan subvariabel yaitu: Y1 kuantitas kerja (quantity of work), Y2 kualitas kerja (quality of work), Y3 pengetahuan tentang pekerjaan (job knowledge), Y4 kreativitas (Creativeness), Y5 kerja sama (cooperative),
Y6 kesalingbergantungan (dependability), Y7 inisiatif (initiative), dan Y8 kualitas personal (personal quality), dapat dilihat pada table 3.

Kuantitas kerja diukur dari item nomor 1 hingga 8 yaitu: jumlah rata-rata hari dimana responden masuk kerja dalam seminggu, jumlah jam kerja yang diperoleh dari penghitungan jam masuk kerja dan jam pulang kerja, jumlah SKS yang diajar dalam satu tahun, jumlah penelitian dalam satu tahun, jumlah pengabdian dalam satu tahun, jumlah mahasiswa yang dibimbing, jumlah mahasiswa bimbingan yang lulus, dan Tabel 3 Hasil Uji Validitas Variabel Perilaku Kerja
Dosen

\begin{tabular}{|c|c|c|c|c|}
\hline $\begin{array}{l}\text { Dimensi } \\
\text { Variabel } \\
\mathrm{X}\end{array}$ & Item & $\begin{array}{l}\text { Koefisien } \\
\text { Validitas } \\
\text { (r hitung) }\end{array}$ & $\begin{array}{l}\text { Titik } \\
\text { Kritis } \\
\mathrm{N}=30 \\
(\mathrm{r} \text { tabel })\end{array}$ & Validitas \\
\hline \multirow[t]{8}{*}{ Y1 } & 1 & 0,428 & 0,361 & Valid \\
\hline & 2 & 0,696 & 0,361 & Valid \\
\hline & 3 & 0,426 & 0,361 & Valid \\
\hline & 4 & 0,588 & 0,361 & Valid \\
\hline & 5 & 0,470 & 0,361 & Valid \\
\hline & 6 & 0,427 & 0,361 & Valid \\
\hline & 7 & 0,435 & 0,361 & Valid \\
\hline & 8 & 0,574 & 0,361 & Valid \\
\hline \multirow[t]{3}{*}{ Y2 } & 10 & 0,683 & 0,361 & Valid \\
\hline & 11 & 0,728 & 0,361 & Valid \\
\hline & 12 & 0,519 & 0,361 & Valid \\
\hline Y3 & 9 & 0,553 & 0,361 & Valid \\
\hline \multirow[t]{3}{*}{ Y4 } & 20 & 0,586 & 0,361 & Valid \\
\hline & 13 & 0,457 & 0,361 & Valid \\
\hline & 14 & 0,459 & 0,361 & Valid \\
\hline \multirow[t]{2}{*}{ Y5 } & 15 & 0,665 & 0,361 & Valid \\
\hline & 18 & 0,562 & 0,361 & Valid \\
\hline \multirow[t]{2}{*}{ Y6 } & 17 & 0,692 & 0,361 & Valid \\
\hline & 22 & 0,640 & 0,361 & Valid \\
\hline \multirow[t]{2}{*}{ Y7 } & 19 & 0,709 & 0,361 & Valid \\
\hline & 23 & 0,439 & 0,361 & Valid \\
\hline \multirow[t]{4}{*}{ Y8 } & 16 & 0,624 & 0,361 & Valid \\
\hline & 21 & 0,641 & 0,361 & Valid \\
\hline & 24 & 0,450 & 0,361 & Valid \\
\hline & 25 & 0,435 & 0,361 & Valid \\
\hline
\end{tabular}

Sumber: Pengolahan data penelitian, 2018 
jumlah publikasi.

Kualitas kerja merupakan kesesuaian mutu hasil kerja dengan tolak ukur yang ditetapkan lembaga diukur dari item nomor 10 sampai dengan 12. Pertanyaan-pertanyaan untuk mengukurnya meliputi responden berusaha menyelesaikan pekerjaan sesuai dengan tolak ukur yang ditetapkan lembaga, responden memberikan kuliah sesuai waktu yang dijadwalkan, dan responden memberikan materi perkuliahan terbaru.

Pengetahuan tentang pekerjaan diukur dengan melakukan tes kognitif pengetahuan responden tentang pekerjaannya. Pertanyaan yang dilemparkan pada responden berkaitan dengan peraturan profesi dosen sesuai dengan peraturan pemerintah. Pada penelitian ini, pertanyaan yang diajukan sebagai berikut:

Kreativitas diukur dari Kemauan memikirkan gagasan baru dan Keberanian menyampaikan gagasan baru. Kemauan memikirkan gagasan baru diwakili oleh pertanyaan responden berusaha memikirkan terobosan-terobosan baru untuk perkembangan lembaga. Keberanian menyampaikan gagasan baru diwakili oleh pertanyaan Responden menyampaikan gagasannya kepada temanteman di lingkungan kerja dan Responden Memberikan masukan yang dapat diterapkan.

Kerja sama merupakan Keinginan untuk bekerja sama dengan orang lain diukur dari Responden Membantu Pekerjaan dosen lain dan Responden berpartisipasi dalam kegiatankegiatan di lingkungan kerja.

Kesalingbergantungan merupakan perilaku Saling bantu dengan dosen lain. Diukur melalui penyataan Responden bersedia untuk saling membantu dalam kelompok dengan dosen lain dan kemauan menyelesaikan pekerjaan dalam satu kelompok kerja.

Inisiatif merupakan diukur dari kemauan menyampaikan gagasan dan kemauan memegang tanggung jawab. Kemauan menyampaikan gagasan diketahui dari pernyataan kemauan menyampaikan gagasan dalam rapat. Sementara itu kemauan memegang tanggung jawab diketahui dari pernyataan responden mau memegang tanggung jawab dalam kegiatan-kegiatan di lingkungan kerja/kepanitiaan dan responden aktif dalam kepanitiaan di kampus.

Kualitas personal diketahui dari empat aspek yaitu Persepsi akan tanggung jawab perkerjaannya, frekuensi diminta nasihat, keramahan terhadap orang lain, dan keikhlasan dalam bekerja. Persepsi akan tanggung jawab pekerjaannya diukur dari responden menyelesaikan tugas-tugas yang menjadi tanggung jawabnya. Frekuensi diminta nasihat diperoleh dari pertanyaan responden sering diminta pendapat oleh teman kerjanya. Keramahan terhadap orang lain diperoleh dari jawaban akan pertanyaan responden senang berbincang-bincang dan beramah tamah dengan teman-temannya. Sementara itu, keihklasan dalam bekerja diperoleh dari jawaban akan pertanyaan responden bersedia menyumbangkan materi pribadi untuk kebaikan pekerjaannya.

Reliabilitas menyangkut ketepatan alat ukur. Reliabilitas mencakup tiga aspek penting, yaitu: alat ukur yang digunakan harus stabil, dapat diandalkan (dependability) dan dapat diramalkan (predictability), sehingga alat ukur tersebut mempunyai reliabilitas yang tinggi atau dapat dipercaya (Neuman, 2014).

Uji reliabilitas data penelitian ini menggunakan rumusan internal consystency method dengan koefisien Alpha Cronbacch's. Koefisien Alpha Cronbach's merupakan koefisien reliabilitas yang paling sering dan paling mudah digunakan (Siegle, 2013). Koefisien ini mampu menggambarkan varians dari item-item baik untuk format benar/salah atau bukan seperti format skala likert, sehingga sekaligus untuk mengevaluasi internal consistency.
Rumus: $\mathrm{r}_{x}=\alpha=\frac{k}{k-1}\left[1-\frac{\sum s_{x}{ }^{2}}{s_{y}{ }^{2}}\right]$
Keterangan:

$\mathrm{r}=$ Nilai koefisien reliabilitas Alpha Cronbach's

$\mathrm{k}=$ Jumlah item pertanyaan

$\mathrm{s}_{x}{ }^{2}=$ Varians masing-masing item

$\mathrm{s}_{y}{ }^{2}=$ Varians skor total

Nilai batas yang digunakan untuk derajat reliabilitas adalah Cronbach's Alpha. Patokan yang umumnya telah diterima secara luas adalah bentuk indikator yang mendapat koefisien lebih besar dari 0,70 dinyatakan reliabel (Siegle, 2013) walaupun angka tersebut bukanlah angka mati. Hal ini berarti, apabila penelitian yang dilakukan bersifat explanatory, maka nilai dibawah 0,70 pun masih dapat diterima, sepanjang disertai alasan-alasan empirik yang terlihat dalam proses eksplorasi. Hayes dan 
Tabel 4 Hasil Uji Reliabilitas

\begin{tabular}{cccc}
\hline Variabel & $\begin{array}{c}\text { Koefisien } \\
\text { Reliabilitas } \\
\text { (A 1 p h a } \\
\text { Cronbach's) }\end{array}$ & $\begin{array}{c}\text { Titik } \\
\text { Kritis } \\
\text { (Cut- } \\
\text { off } \\
\text { Points) }\end{array}$ & Kesimpulan \\
\hline $\begin{array}{c}\text { Kekerasan } \\
\text { Komunikasi } \\
\text { Pada }\end{array}$ & 0,754 & 0,700 & Reliabel \\
$\begin{array}{c}\text { Kelompok } \\
\text { Percakapan } \\
\text { WhatsApp }\end{array}$ & & & \\
$\begin{array}{c}\text { Emosi } \\
\text { Pe ri la k u }\end{array}$ & 0,744 & 0,700 & Reliabel \\
Kerja Dosen & 0,755 & 0,700 & Reliabel \\
\hline
\end{tabular}

Sumber: Pengolahan data penelitian, 2018

Krippendorf menyatakan bahwa koefisien Alpha Cronbach 0,7 adalah sedang (modest) (Hayes \& Krippendorff, 2007). Sementara itu, Sekaran dan Boogie menyebut bahwa titik kritis koefisien Alpha Cronbach agar instumen dinyatakan reliabel adalah 0,6 . Koefisien antara 0,6 hingga 0,7 dinyatakan kurang baik (poor). Nilai koefisien di atas 0,7 adalah dapat diterima (acceptable) (Sekaran \& Bougie, 2010).

Uji validitas pada penelitian ini dilakukan dengan program IBM SPSS Statistic Versi 22, yang hasilnya dapat dilihat pada tabel 4 . Hasil uji reliabilitas ini menunjukkan bahwa ketiga variabel tersebut dapat digunakan untuk penelitian tentang kekerasan komunikasi, emosi, dan perilaku kerja di lingkungan dosen.

\section{SIMPULAN}

Penelitian mengenai pengembangan instrumen pengukuran kekerasan komunikasi pada kelompok WhatsApp di lingkungan kerja dosen ini, berhasil merumuskan alat ukur yang valid dan reliable dengan harapan dapat membantu bagi peneliti-peneliti lain yang ingin meneliti fenomena sejenis, karena penelitian sejenis yang masih sangat jarang di Indonesia. Penyusunan instrumen telah dilakukan dengan menggunakan sumber-sumber yang kredibel berupa buku, artikel ilmiah, dan peraturan pemerintah.

Dari penelitian pengembangan instrumen pengukuran kekerasan komunikasi pada kelompok WhatsApp di lingkungan kerja dosen ini diperoleh simpulan sebagai berikut: 1) Kekerasan komunikasi dapat diukur dari tiga dimensi yaitu bentuk kekerasan, repetisi, dan kesenjangan; 2) emosi dapat diukur dari dua dimensi yaitu emosi positif dan emosi negatif; dan 3) Perilaku kerja dapat diukur dari kuantitas kerja (quantity of work), kualitas kerja (quality of work), pengetahuan tentang pekerjaan (job knowledge), kreativitas (creativeness), kerja sama (cooperative), kesalingbergantungan (dependability), inisiatif (initiative), dan kualitas personal (personal quality).

Penelitian dengan menggunakan instumeninstrumen ini hendaknya dilakukan dengan kerangka Affective Events Theory karena teori ini menyediakan model yang secara eksplisit menyebutkan emosi dan perilaku kerja sebagai variable yang mengikuti peristiwaperistiwa yang terjadi dalam lingkup organisasi atau dunia kerja. Selain itu, penelitian juga sebaiknya dilakukan dengan structural equational modelling (SEM). Pengujian SEM menyarankan dilakukannya confirmatory factor analysis, dengan demikian pertanyaanpertanyaan dalam instrumen ini akan melalui konfirmasi sehingga hanya pertanyaan yang fit yang diuji pengaruhnya.

\section{DAFTAR PUSTAKA}

Adler, E. S. \& Clark, R. (2014). An invitation to social research: how it's done. Standford: Cengage Learning.

Babbie, E. R. (2011). The basic of social research, 5th ed. Belmont California: Wardsworth Cengage Learning.

Basch, J. \& Fisher, C. (1998). Affective eventsemotions matrix: A classification of work events and associated emotions. School of Business Discussion Papers.

Bauman, S., Toomey, R. B., \& Walker, J. L. (2013). Associations among bullying, cyberbullying, and suicide in high school students. Journal of Adolescent, 36(2). https://doi.org/Associations among bullying, cyberbullying, and suicide in high school students.

Bless, C., Higson-Smith, C., \& Sithole, S. L. (2013). Fundamentals of social research methods: an African perspective. Cape Town: Juta.

Creed, A. \& Zutshi, A. (2012). Social media: 
does it generate the continuum of transparency in organisation. in a. z. andrew creed. in public interest and private rights in social media (p. 129). Oxford: Chandos Publishing Social Media Series.

D'Cruz, P. \& Noronha, E. (2013). Navigating the extended reach: target experiences of cyberbullying at work. Journal of Information and Organization, 324-343.

Farley, S. (2015). Exploring the impact of cyberbullying on trainee doctors. Medical Education, 438-443.

Gomes, F. C. (2003). Manajemen sumber daya manusia. Yogyakarta: Andi.

Grimms, P. (2010). Pretesting a questionnaire. in wiley international encyclopedia of marketing. John Wiley \& Sons.

Hayes, A. F. \& Krippendorff, K. (2007). Answering the Call for a standard reliability measure for coding data. Communication Methods And Measures, 77-89.

Heatherington, W. \& Coyne, I. (2014). Understanding idividual experiences of cyberbullying encountered through work. International Journal of Organization Theory And Behavior, 17(2), 163-192.

Keskin, H., Ekber Akgün, A., Ayar, H., \& Kayman, Ş. (2016). Cyberbullying victimization, counterproductive work behaviours and emotional intelligence at workplace. Procedia-Social and Behavioral Sciences, 235, 281-287. https:// doi.org/10.1016/j.sbspro.2016.11.031.

Lawson, C. (2015). Makin populernya "chat online" di tempat kerja. Retrieved August 28, 2018, from BBC Indonesia website: http://www.bbc.com/indonesia/ majalah/2015/11/151127_majalah_chat_ tempatkerja.

Mann, P. S. \& Lackee, C. J. (2010). Introductory statistic, 7th Ed. Denver: John Wiley \& Son.

Mirawati, I., Suryana, A., Agustin, H., \& Hidayat, M. (2019). Identifying the victims of workplace cyberbullying among lecturers. Jurnal Studi Komunikasi (Indonesian Journal of Communications Studies), 3(2), 151. https://doi.org/10.25139/jsk. v3i2.1535.

Mirawati, I., Suryana, A., Hidayat, M., \& Agustin, H. (2018). Gender differences in workplace humor among lecturers: study on whatsapp group(s). International Journal of Engineering \& Technology, 7(2.29), 628. https://doi.org/10.14419/ijet. v7i2.29.13987.

Mishna, F., Saini, M., \& Solomon, S. (2009). Ongoing and online: children and youth's perceptions of cyber bullying. Children and Youth Services Review, 31(12), 1222-1228. https://doi.org/10.1016/j. childyouth.2009.05.004.

Neuman, W. (2014). Social research methods: qualitative and quantitative approaches. In Teaching Sociology (Vol. 30). https://doi. org/10.2307/3211488.

Pirola-Merlo, A., Härtel, C., Mann, L., \& Hirst, G. (2002). How leaders influence the impact of affective events on team climate and performance in R\&D teams. The Leadership Quarterly, 13(5), 561581. https://doi.org/10.1016/S10489843(02)00144-3.

Pribadi, B. A. (2006). Ketersediaan dan pemanfaatan media dan teknologi pembelajaran di perguruan tinggi. Retrieved April 23, 2017, from Universitas Terbuka website: http://pk.ut.ac.id/ jp/52sept04/52benny.htm.

Privitera, C. \& Campbel, M. A. (2009). Cyberbullying: the new face of workplace bullying. Journal of CyberPsychology and Behavior, 395-400.

Purcell, K., Heaps, A., Judy, B., \& Linda Friendrich. (2016). How teachers are using technology at home and in their classrooms. Retrieved April 24, 2017, from Pew Research Center: Internet, Science, and Tech website: http://www. pewInternet.org/2013/02/28/how-teachersare-using-technology-at-home-and-intheir-classrooms/.

Randall, P. (2001). Bullying in adulthood: sssessing the bullies and their victims. New York: Routledge.

Randall, P. (2005). Adult bullying: perpetrators and victims (T. \& F. E-Library, Ed.). New York.

Robbins, S. P. \& Judge, T. (2008). Essentials of organizational behavior, 9th Edition. San Diego: Pearson.

Roland E Pittman. (2016). Taxonomy of learning: a brief introduction. Retrieved from https://books.google.co.id/ 
books?id=L6mShwpMdP4C: PediaPress.

Rosenberg, M. B. (2005). Speak peace in a world of conflict: what you say next will change your world. San Fransisco: Puddle Dancer Press.

Sekaran, U. \& Bougie, R. (2010). Research methods for business: A skill building approach (5th ed.). New York: John Wiley \& Son.

Siegle, D. (2013). Instrument reliability. Retrieved from University of Connecticut Educational Research Basics website: https://researchbasics.education.uconn. edu/instrument_reliability/.

Sletto, R. F. (1940). Pretesting questionaires. American Sociological Review Vol.5 No.2.

Smith, P. K., Bario, C. Del, \& Tokunaga, R. S. (2013). Definition of bullying and cyberbullying. in principles of cyberbullying research: definitions, measures, and methodology. New York: Routledge.

Tourish, D. \& Hargie, O. (2003). Key issues in organizational communication. Key Issues in Organizational Communication, 1-304. https://doi.org/10.4324/9780203634394.

Weiss, H. M. \& Beal, D. (2005). Reflections on affective events theory. Research on Emotion in Organizations, 1, 1-21. https:// doi.org/10.1016/S1746-9791(05)01101-6.

West, B., Foster, M., Levin, A., Edmison, J., \& Robirero, D. (2014). Cyberbullying at work: In Search of Effective Guide. Laws, 3, 598-617.

Yogisusanti, G., Kusnanto, H., Setyawati, L., \& Otsuka, Y. (2014). Faktor penyebab kelelahan kerja pada dosen (studi kualitatif pada dosen sekolah tinggi ilmu kesehatan swasta di Jawa Barat). Jurnal Ilmu Kesehatan, 7(7), 1-13. 